Article

\title{
Protective Effects of Myo-Inositol and Selenium on Cadmium-Induced Thyroid Toxicity in Mice
}

\author{
Salvatore Benvenga ${ }^{1,+}$, Herbert R. Marini ${ }^{1,+} \oplus$, Antonio Micali ${ }^{2, *}$, Jose Freni ${ }^{2}$, \\ Giovanni Pallio ${ }^{1}{ }^{\mathbb{D}}$, Natasha Irrera ${ }^{1}$, Francesco Squadrito ${ }^{1}{ }^{(\mathbb{D}}$, Domenica Altavilla ${ }^{2}$, \\ Alessandro Antonelli ${ }^{3}{ }^{\circledR 0}$, Silvia Martina Ferrari ${ }^{3}$, Poupak Fallahi ${ }^{3}$, Domenico Puzzolo ${ }^{2}$ \\ and Letteria Minutoli ${ }^{1}$ \\ 1 Department of Clinical and Experimental Medicine, University of Messina, 98125 Messina, Italy; \\ s.benvenga@live.it (S.B.); hrmarini@unime.it (H.R.M.); gpallio@unime.it (G.P.); nirrera@unime.it (N.I.); \\ fsquadrito@unime.it (F.S.); lminutoli@unime.it (L.M.) \\ 2 Department of Biomedical and Dental Sciences and Morphofunctional Imaging, University of Messina, \\ 98125 Messina, Italy; freni.jose@gmail.com (J.F.); daltavilla@unime.it (D.A.); puzzolo@unime.it (D.P.) \\ 3 Department of Clinical and Experimental Medicine, University of Pisa, 56126 Pisa, Italy; \\ alessandro.antonelli@med.unipi.it (A.A.); sm.ferrari@int.med.unipi.it (S.M.F.); poupak.fallahi@unipi.it (P.F.) \\ * Correspondence: amicali@unime.it; Tel.: +39-090-692427; Fax: +39-090-2213630 \\ + Both authors equally contributed.
}

Received: 25 March 2020; Accepted: 23 April 2020; Published: 26 April 2020

\begin{abstract}
Cadmium (Cd) damages the thyroid gland. We evaluated the effects of myo-inositol (MI), seleno-L-methionine (Se) or their combination on the thyroids of mice simultaneously administered with $\mathrm{Cd}$ chloride $\left(\mathrm{CdCl}_{2}\right)$. Eighty-four male mice were divided into 12 groups (seven mice each). Six groups (controls) were treated with $0.9 \% \mathrm{NaCl}$ (vehicle), Se $(0.2 \mathrm{mg} / \mathrm{kg} /$ day), Se $(0.4 \mathrm{mg} / \mathrm{kg} / \mathrm{day})$, MI $(360 \mathrm{mg} / \mathrm{kg} /$ day), MI+Se $(0.2 \mathrm{mg} / \mathrm{kg})$ and MI+Se $(0.4 \mathrm{mg} / \mathrm{kg})$. The other six groups were treated with $\mathrm{CdCl}_{2}(2 \mathrm{mg} / \mathrm{kg}), \mathrm{CdCl}_{2}+\mathrm{MI}, \mathrm{CdCl}_{2}+\mathrm{Se}(0.2 \mathrm{mg} / \mathrm{kg}), \mathrm{CdCl}_{2}+\mathrm{Se}(0.4 \mathrm{mg} / \mathrm{kg}), \mathrm{CdCl}_{2}+\mathrm{MI}+\mathrm{Se}$ $(0.2 \mathrm{mg} / \mathrm{kg})$ and $\mathrm{CdCl}_{2}+\mathrm{MI}+\mathrm{Se}(0.4 \mathrm{mg} / \mathrm{kg})$. An additional group of $\mathrm{CdCl}_{2}$-challenged animals $(\mathrm{n}=7)$ was treated with resveratrol $(20 \mathrm{mg} / \mathrm{kg})$, an effective and potent antioxidant. All treatments lasted 14 days. After sacrifice, the thyroids were evaluated histologically and immunohistochemically. $\mathrm{CdCl}_{2}$ reduced the follicular area, increased the epithelial height, stroma, and cells expressing monocyte chemoattractant protein-1 (MCP-1) and C-X-C motif chemokine 10 (CXCL10). $\mathrm{CdCl}_{2}+\mathrm{Se}$ at $0.2 / 0.4 \mathrm{mg} / \mathrm{kg}$ insignificantly reversed the follicular and stromal structure, and significantly decreased the number of MCP-1 and CXCL10-positive cells. $\mathrm{CdCl}_{2}+\mathrm{MI}$ significantly reversed the thyroid structure and further decreased the number of MCP-1 and CXCL10-positive cells. CdCl ${ }_{2}+\mathrm{MI}+\mathrm{Se}$, at both doses, brought all indices to those of $\mathrm{CdCl}_{2}$-untreated mice. MI, particularly in association with Se, defends mice from Cd-induced damage. The efficacy of this combination was greater than that of resveratrol, at least when using the follicular structure as a read-out for a comparison. We suggest that the use of these nutraceuticals, more specifically the combination of MI plus SE, can protect the thyroid of Cd-exposed subjects.
\end{abstract}

Keywords: cadmium; nutraceuticals; myo-inositol; seleno-L-methionine; thyroid; MCP-1; CXCL10

\section{Introduction}

Thyroid disorders, including hypothyroidism, with its leading etiology (Hashimoto's thyroiditis) and cancer arising from the follicular epithelium, are very common diseases [1,2]. Indeed, with a prevalence of $10 \%-12 \%$ in the general population, Hashimoto's thyroiditis is the most common autoimmune disease [1]. The prevalence of thyroid cancer has increased considerably in recent decades. 
Thyroid cancer incidence was relatively stable until the 1990s, when it began to increase dramatically. Overall, thyroid cancer incidence increased from 4.9 per 100,000 population to 14.7 per 100,000 population in 2011 [2]. Dysfunction, autoimmunity and cancer of the thyroid are triggered by environmental factors, including pollutants such as organochlorine compounds, polychlorinated biphenyls, polybrominated diphenylethers, bisphenol A, triclosan, perchlorates, thiocyanates, nitrates and heavy metals [3-8].

One such heavy metal is cadmium (Cd). $\mathrm{Cd}$ is found in food, cigarette smoke, mines, phosphate fertilizers and nickel-cadmium batteries [9]. Cd enters the body through the gastrointestinal tract and the alveolar epithelium [9] and passes through the systemic circulation, bound to albumin. Cd is then transported to the liver, where it is released and induces the synthesis of metallothionein (MT), a stress protein first discovered in 1957 in horse kidneys [10], which protects against Cd toxicity and oxidative stress [11]. The complex MT-Cd accumulates in the liver, kidneys, skeletal muscles and thyroid. With a biological half-life of 5 to 30 years, exposure over time to even environmentally low levels of $\mathrm{Cd}$ is associated with several toxic effects on the liver, kidneys, bones, testes and the cardiovascular system [12-15]. Persons living in Cd-polluted areas have an intrathyroid concentration of Cd that is threefold greater than control persons [16]. Finally, $\mathrm{Cd}$ has been classified as a group 1 human carcinogen, with evidence existing of its association with lung, prostate and kidney cancers [17], and a possible association with other malignancies, such as breast [18], pancreas [19], and urinary bladder cancer [20]. Concerning thyroid cancer, a recent study on 66 patients with papillary thyroid cancer (PTC) showed that the content of selenium (Se) was significantly decreased (66 vs. $132 \mathrm{ng} / \mathrm{g}$ ), while the content of Cd ( $58 \mathrm{vs.} 33 \mathrm{ng} / \mathrm{g}$ ) and the resulting Cd/Se ratio (0.055 vs. 0.018$)$ were significantly higher in the cancerous tissue compared to the healthy, noncancerous thyroid tissue [21]. Furthermore, $\mathrm{Cd}$ and the $\mathrm{Cd} / \mathrm{Se}$ ratio were associated with the retrosternal thyroid growth of PTC [21].

$\mathrm{Cd}$ increases serum thyrotropin (TSH) concentration in rats [22,23] and humans [24]. After chronic exposure to $\mathrm{Cd}$, the presence of desquamated cells in the follicles, mononuclear cell infiltration in the connective tissue and follicles lined by higher cells with light cytoplasm were observed [25]. In a similar manner to mercury $(\mathrm{Hg})$, the interaction of $\mathrm{Cd}$ with $\mathrm{Se}$, which is relatively abundant in the thyroid [26], as the inorganic component of the deiodinases [27-29], results in formation of insoluble complexes $[27,28,30]$. The consequence of such sequestration of Se is the impairment of selenoprotein synthesis and activities [28]. In over 5000 Chinese adults, blood levels of both Cd and lead $(\mathrm{Pb})$ were directly correlated with both thyroid hypofunction and serum thyroid autoantibody levels [31], even if the risk of hypothyroidism increased incrementally with blood cadmium in men, but not in women [32]. In the study on 5628 Chinese adults, women showed a positive correlation between $\log (\mathrm{ln})$-transformed blood concentrations of $\mathrm{Cd}$ and $\log (\ln )$-transformed blood concentrations of thyroglobulin autoantibodies $(\mathrm{TgAb})$ [31]. In the adjusted logistic regression models, the $\log (\mathrm{ln})$-transformed blood concentrations of $\mathrm{Cd}$ of women were positively related to their $\mathrm{Tg} \mathrm{Ab}$ tertiles and hypothyroid status [31]. Cd exposure also causes increased susceptibility to testicular autoimmunity [33]. Indeed, the role of $\mathrm{Cd}$ in autoimmunity is supported by studies on 24 individuals, in whom the authors measured the blood levels of three heavy metals $(\mathrm{Cd}, \mathrm{Hg}$ and $\mathrm{Pb}$ ) and blood mRNA expression of 98 genes that are implicated in stress, toxicity, inflammation, and autoimmunity [34].

Among the different mechanisms involved in Cd-induced thyroid damage (genome influence, apoptosis, mitochondrial dysfunction, oxidative stress), the the last mechanism seems to play a relevant role [24]. Indeed, the said depletion of Se stores leads to its decreased availability to form glutathione (GSH) peroxidase, which is one of the main natural antioxidants [35]. Se supplementation exerts some beneficial effects on the thyroid of Cd-exposed rats. Histopathological analysis of the thyroid of young rats whose mothers received $\mathrm{Cd}$ during pregnancy demonstrated the presence of microfollicles lined by a single layer of columnar epithelium; $\mathrm{Cd}$ administration resulted in a sharp decrease in the height of epithelial cells [36]. Furthermore, treatment of Cd-exposed rats with Se partially attenuated the Cd-induced decrease in serum T4 levels [22]. 
Beneficial effects against $\mathrm{Cd}$-induced damage of the thyroid or other organs were also described for other naturally occurring molecules that, like Se, are used as nutraceuticals. These molecules are quercetin [37] and myo-inositol (MI) [38-40]. Quercetin significantly increased serum thyroid hormones in rats treated with $\mathrm{CdCl} 2$, even if levels were significantly lower compared to unchallenged rats [37]. In mice, a 14-day treatment with $\mathrm{CdCl}_{2}(2 \mathrm{mg} / \mathrm{kg} /$ day) plus MI (360 mg/kg/day) protected the testis [39] and the kidney [40] from the damage induced by $\mathrm{CdCl}_{2}$. The $\mathrm{Cd}$-induced testicular damage consisted of smaller tubules, the discontinuity of the seminiferous epithelium, the detachment of spermatogonia from the basal membrane, and reduced claudin-11 immunoreactivity [39]. The Cd-induced renal damage consisted of alterations in glomerular and tubular morphology [40]. Concerning the testis, experiments were also conducted with Se alone and with a combination MI plus Se-L-methionine [39], with such a combination having the greatest protective effects on the seminiferous tubules, and in particular on the blood-testis barrier.

Aside from the Cd setting, the beneficial effects of MI have been shown in human sperm [41,42] and oocytes [43]. The antioxidant properties of MI are demonstrated by the MI-induced increase in the intracellular levels of GSH, superoxide dismutase (SOD) and catalase (CAT) [44]. Starting from the knowledge that chemokines are mechanistically involved in the initiation and maintenance of Hashimoto's thyroiditis $[45,46]$, it was shown that MI and, to a greater extent, the combination of MI plus Se-L-methionine, decreased serum levels and lymphocyte secretion of the investigated chemokines $[47,48]$. These chemokines were chemokine (C-C motif) ligand 2 (CCL2; also known as monocyte chemoattractant protein-1 (MCP-1)), C-X-C motif chemokine 9 (CXCL9; also known as monokine induced by gamma interferon (MIG)), and C-X-C motif chemokine 10 (CXCL10). Such effects on chemokines explain the benefits of the combination of MI plus Se-L-methionine in patients with Hashimoto's thyroiditis, in terms of decreased oxidative stress [38], decreased serum levels of thyroid autoantibodies and an improved hormone profile [47-49].

Based on this background, considering (i) that no morphometric analysis has been conducted in previous studies on protection from Cd-induced thyroid damage [24,36,50], (ii) the lack of data regarding the effects of MI alone and the association of MI plus Se with Cd-induced thyroid damage, and (iii) that MI, Se and other natural compounds are being increasingly used as nutraceuticals in clinical practice [38], we aimed to demonstrate their protective role in the structure of thyroid glands in mice exposed to $\mathrm{Cd}$. We also wished to test whether $\mathrm{Cd}$ induced the expression of two aforementioned chemokines (MCP-1/CCL2 and CXCL10) and, if so, to test whether this expression could be counteracted by MI, Se or their combination.

\section{Materials and Methods}

\subsection{Experimental Protocol}

All procedures adhered to the standards for care and use of animals as per guidelines issued by Animal Research Reporting in Vivo Experiments (ARRIVE); the procedures were evaluated and approved by the Italian Health Ministry (project identification code: 112/2017-PR). Eighty-four male C57 BL/6J mice (25-30 g) were obtained from Charles River Laboratories Italia Srl (Calco, LC, Italy) and stored at the animal house faculty of our university hospital. A standard diet was provided ad libitum and the animals had free access to water; they were kept on a 12-h light/dark cycle. The animals were randomly distributed into twelve groups of seven mice each. Six groups (viz. 42 mice) were considered as controls $(0.9 \% \mathrm{NaCl}$ (vehicle, $1 \mathrm{~mL} / \mathrm{kg}$ ), seleno-L-methionine (Se) $(0.2 \mathrm{mg} / \mathrm{kg})$, Se $(0.4 \mathrm{mg} / \mathrm{kg})$, MI (360 mg/kg), MI (360 mg/kg) plus Se (0.2 mg/kg), MI (360 mg/kg) plus Se $(0.4 \mathrm{mg} / \mathrm{kg}))$. The other six groups were challenged with $\mathrm{CdCl}_{2}(2 \mathrm{mg} / \mathrm{kg})$ plus a vehicle, $\mathrm{CdCl}_{2}(2 \mathrm{mg} / \mathrm{kg})$ plus MI $(360 \mathrm{mg} / \mathrm{kg})$, $\mathrm{CdCl}_{2}(2 \mathrm{mg} / \mathrm{kg})$ plus Se $(0.2 \mathrm{mg} / \mathrm{kg}), \mathrm{CdCl}_{2}(2 \mathrm{mg} / \mathrm{kg})$ plus Se $(0.4 \mathrm{mg} / \mathrm{kg}), \mathrm{CdCl}_{2}(2 \mathrm{mg} / \mathrm{kg})$ plus MI $(360 \mathrm{mg} / \mathrm{kg})$ plus Se $(0.2 \mathrm{mg} / \mathrm{kg})$ and $\mathrm{CdCl}_{2}(2 \mathrm{mg} / \mathrm{kg})$ plus MI $(360 \mathrm{mg} / \mathrm{kg})$ plus Se $(0.4 \mathrm{mg} / \mathrm{kg})$. An additional group of $\mathrm{CdCl}_{2}$-challenged animals $(n=7)$ were given $20 \mathrm{mg} / \mathrm{kg}$ of resveratrol [51,52], a biologically active compound with potent antioxidant properties [53]. $\mathrm{CdCl}_{2}$ and $\mathrm{NaCl}$ were 
administered intraperitoneally (i.p.), while MI, Se and resveratrol per os. MI was ready for use, while $\mathrm{CdCl}_{2}$ and Se were diluted in $0.9 \% \mathrm{NaCl}$ before use. After 14 days of treatment, mice were sacrificed with an overdose of ketamine and xylazine, and their thyroids were collected and processed for histological and immunohistochemical procedures.

\subsection{Histological Evaluation}

The thyroid glands were fixed in $4 \%$ paraformaldehyde in $0.2 \mathrm{M}$ phosphate buffer saline (PBS), dehydrated in ethanol, cleared in xylene and embedded in Paraplast (SPI Supplies, West Chester, PA, USA). Blocks were cut in a microtome (RM2125 RT, Leica Instruments, Nussloch, Germany), and $5 \mu \mathrm{m}$ sections were cleared with xylene, rehydrated in ethanol and stained with hematoxylin and eosin (HE) and Sirius red (SR). All samples were observed with a Nikon Ci-L (Nikon Instruments, Tokyo, Japan) light microscope and the micrographs were obtained using a digital camera (Nikon Ds-Ri2) and saved as Tagged Image Format Files (TIFF) with the Adobe Photoshop CS5 12.1 software.

\subsection{Immunohistochemistry for Monocyte Chemoattractant Protein-1 (MCP-1) and C-X-C Motif Chemokine 10 (CXCL10)}

The same specimens used for histological evaluation were cut at $5 \mu \mathrm{m}$ and the sections were placed on polysine slides (Thermo Fisher Scientific, Waltham, MA, USA), cleared with xylene and rehydrated in ethanol. Antigen retrieval was obtained in buffer citrate $\mathrm{pH}$ 6.0; endogenous peroxidase was blocked with $0.3 \% \mathrm{H}_{2} \mathrm{O}_{2}$ in PBS. Incubation with primary antibodies (MCP-1, 1:150, Santa Cruz, Dallas, TX, USA; CXCL10, 1:100, Biorbyt, Cambridge, UK) was performed overnight at $4{ }^{\circ} \mathrm{C}$ in a moisturized chamber; then, secondary antibodies (anti-mouse and anti-rabbit, Vectastain, Vector, Burlingame, CA, USA) were added, and the reaction was evidenced with 3,3'-diaminobenzidine (DAB) (Sigma-Aldrich, Milan, Italy). Slides were counterstained in Mayer's hematoxylin. For each test, specific positive and negative controls were prepared. Micrographs were taken with a Nikon Ci-L (Nikon Instruments, Tokyo, Japan) light microscope using a digital camera (Nikon Ds-Ri2).

\subsection{Morphometric and Immunohistochemical Evaluation}

All micrographs were printed at the same final magnification $(800 \times)$ and were blindly assessed by two trained observers, without knowledge of the previous treatment. Five microscopic fields (MFs), all including two entire thyroid follicles from ten non-serial sections stained with the HE of each group were considered.

As for the follicular compartment, a Peak Scale Loupe 7× (GWJ Company, Hacienda Heights, CA, USA) micrometer was used as a scale calibration standard to estimate the follicular diameters. The area (A) of each follicle was calculated by measuring the smaller inner diameter (d) and the larger inner diameter $(\mathrm{D})$ of the follicle, both expressed in micrometers $(\mu \mathrm{m})$. The estimated area of the follicular lumen was obtained by the following formula:

$$
\mathrm{A}=\pi \cdot(\mathrm{d} / 2 . \mathrm{D} / 2)
$$

In each thyroid gland, we measured the area of 20 follicles. To calculate the epithelial height, a straight line perpendicular to the epithelium was traced and measured, and the results were expressed in micrometers.

For the evaluation of the stroma, a quantitative study of micrographs from 20 microscopic fields of Sirius Red (SR)-stained not-serial sections for each group was performed with the Adobe Photoshop CS5 12.1 software, acquiring the pink/red color of collagen fibers. Positive areas were automatically calculated based on their pixel number. Values were indicated as the pixel number of the positively stained area/unit area (UA). The area of the entire micrograph was evaluated as the UA.

For an assessment of the immunoreactivity of MCP-1/CCL2 and CXCL10, positive cells were counted from 10 non-serial sections of the thyroid, selecting two unit areas (UA) of $0.1 \mathrm{~mm}^{2}$ 
$(316 \times 316 \mu \mathrm{m})$. Cells overlapping the right and top borders of the areas were not counted, while the cells overlapping the left and the bottom borders were considered.

\subsection{Drugs and Chemicals}

$\mathrm{CdCl}_{2}$, Se and resveratrol were bought from Sigma-Aldrich Srl (Milan, Italy). LO.LI. Pharma Srl (Rome, Italy) kindly provided MI. All chemicals not otherwise mentioned were commercially available reagent grade quality.

\subsection{Statistical Analysis}

Values are expressed as the mean \pm standard error (SE). The statistical significance of differences between group mean values was established using Student's t-test. The statistical evaluation of differences among groups was obtained with ANOVA. The statistical analysis of histological scores was done using the Mann-Whitney $\mathrm{U}$ test with Bonferroni correction. A $p$ value of $\leq 0.05$ was considered statistically significant.

\section{Results}

\subsection{Histopathological Data}

\subsubsection{Follicular Epithelium}

Images are presented in Figure $1 \mathrm{~A}-\mathrm{G}$, with the quantification of the follicular area and the height of the follicular epithelium (thyrocytes) summarized in Figure $1 \mathrm{H}-\mathrm{I}$.

All control animals had thyroids with normal morphologies (results not shown). Therefore, for sake of simplicity, we present a single micrograph as representative of controls (Figure 1A). In the thyroid of mice challenged with $\mathrm{CdCl}_{2}$, compared to controls, the follicular area was smaller and thyrocytes were taller but poorly stained (Figure 1B). In the thyroid of mice treated with $\mathrm{CdCl}_{2}$ plus either dose of Se, compared to controls, the follicular area was also dose-dependently significantly smaller and the follicular epithelium was also dose-dependently significantly taller (Figure 1C,D), though the area and height changed to a lesser degree compared to mice treated with $\mathrm{CdCl}_{2}$ alone (compare Figure 1C,D with Figure 1B, and corresponding points in Figure 1H,I). In the thyroid of mice treated with $\mathrm{CdCl}_{2}$ plus MI, compared to controls, the follicular area was also significantly smaller, and the follicular epithelium was significantly taller (Figure 1E), while both the area and height changed to an even lesser degree compared to mice treated with $\mathrm{CdCl}_{2}$ plus either dose of Se (compare Figure $1 \mathrm{E}$ with Figure 1B, and corresponding points in Figure 1H,I). In mice treated with $\mathrm{CdCl}_{2}$ plus both $\mathrm{MI}$ and Se at either 0.2 or $0.4 \mathrm{mg} / \mathrm{kg}$, the follicular area and epithelial height were no longer statistically different from the controls (Figure $1 F, G$ ), but both indices were statistically different from their counterparts in the other treated mice (compare Figure 1F, G with Figure 1B,G, and corresponding points in Figure 1H,I). Furthermore, the effect of the combination of MI plus Se on the follicular area and epithelial height was greater than that brought about by resveratrol, used for its potent antioxidant properties (see Supplemental materials Figure S1). 
A
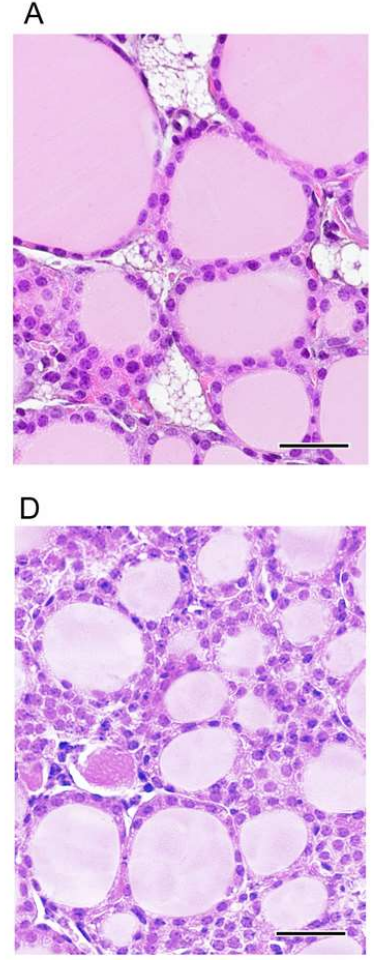

G

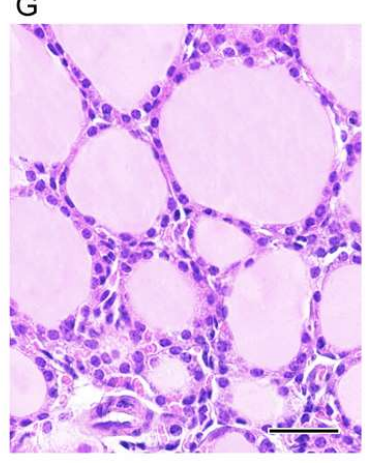

B

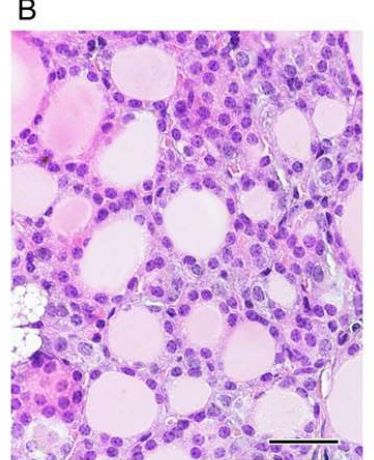

E
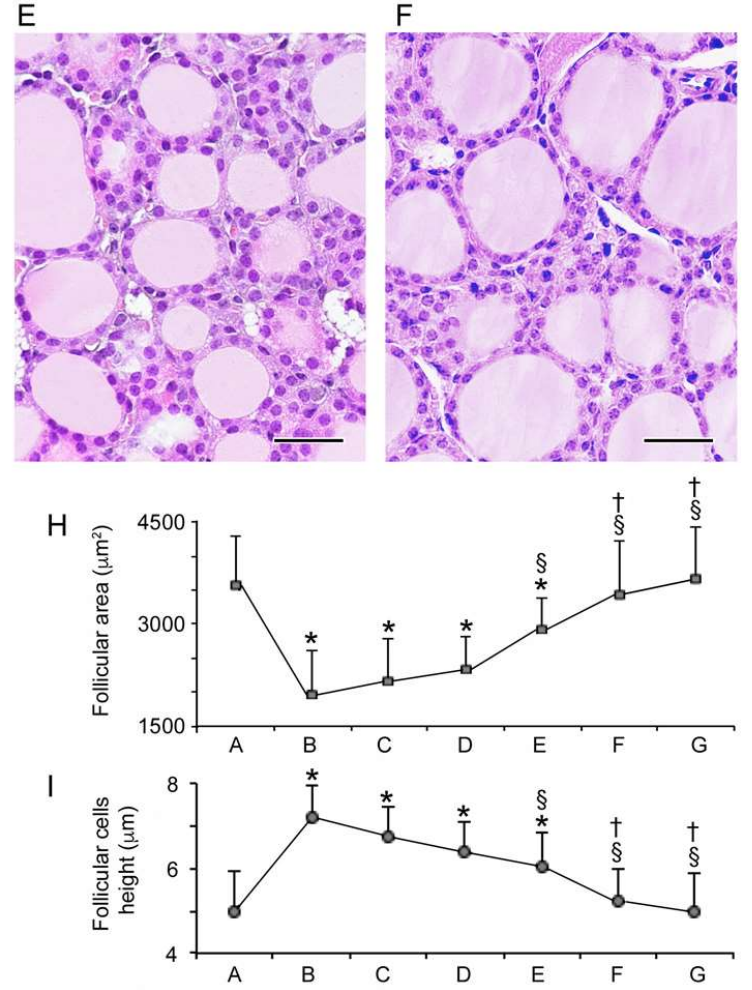

Figure 1. Histological organization of the thyroid (hematoxylin-eosin stain; scale bar: $25 \mu \mathrm{m}$ ). Mice groups (seven mice/group) are: controls (A), cadmium chloride $\left(\mathrm{CdCl}_{2}\right)$ plus vehicle $(\mathbf{B}), \mathrm{CdCl}_{2}$ plus seleno-L-methionine (Se) $0.2 \mathrm{mg} / \mathrm{kg}(\mathbf{C}), \mathrm{CdCl}_{2}$ plus Se $0.4 \mathrm{mg} / \mathrm{kg}$ (D), $\mathrm{CdCl}_{2}$ plus myo-inositol (MI) (E), $\mathrm{CdCl}_{2}$ plus MI plus Se $0.2 \mathrm{mg} / \mathrm{kg}(\mathbf{F}), \mathrm{CdCl}_{2}$ plus MI plus Se $0.4 \mathrm{mg} / \mathrm{kg}(\mathbf{G})$. A: Control mice have a normal thyroid structure, as demonstrated also by bar A in $\mathrm{H}$ and I. $\mathrm{B}: \mathrm{CdCl}_{2}$-treated mice show small follicles and less stainable follicular epithelium (thyrocytes), the height of which is increased, as shown by bar B in (H,I). C-D: In mice treated with $\mathrm{CdCl}_{2}$ plus $0.2 \mathrm{mg} / \mathrm{Kg}$ Se or $\mathrm{CdCl}_{2}$ plus $0.4 \mathrm{mg} / \mathrm{kg}$ Se, small follicles are present with thyrocytes of smaller height, as indicated by bars C and D in $\mathrm{H}$ and I. E: In mice treated with $\mathrm{CdCl}_{2}$ plus $\mathrm{MI}$, the follicles and thyrocytes show a tendency to acquire a normal size and height, even though both indices are significantly different from the controls; see also bar $\mathrm{E}$ in $\mathrm{H}$ and I. F-G: In mice treated with $\mathrm{CdCl}_{2}$ plus MI and $0.2 \mathrm{mg} / \mathrm{Kg} \mathrm{Se}$ or $\mathrm{CdCl}_{2}$ plus $\mathrm{MI}$ and $0.4 \mathrm{mg} / \mathrm{kg} \mathrm{Se}$, follicles and epithelial cells were close to normal, as demonstrated by bars F and G in H and I. H: Mean \pm standard error values of follicular area in the different groups of mice. I: Mean \pm standard error values of epithelial cells height in the different groups of mice. ${ }^{*} p<0.05$ versus control; $\S p<0.05$ versus $\mathrm{CdCl}_{2}$ plus vehicle and $\mathrm{CdCl}_{2}$ plus 0.2 or $0.4 \mathrm{mg} / \mathrm{kg}$ Se; $+p<0.05$ versus $\mathrm{CdCl}_{2}$ plus $\mathrm{MI}$ alone.

\subsubsection{Stroma}

As indicated in the Materials and Methods, Sirius Red staining allowed us to quantify the thyroid stroma, since stromal areas are positive to such staining. Positive areas were quantified by a software 
based on their pixel number. Data were expressed as the pixel number of the positively stained area/unit area (UA), considered to be the entire micrograph area. Matching the illustration of data for the epithelium (see above), images are presented in Figure 2A-G, with quantification also summarized in Figure $2 \mathrm{H}$.
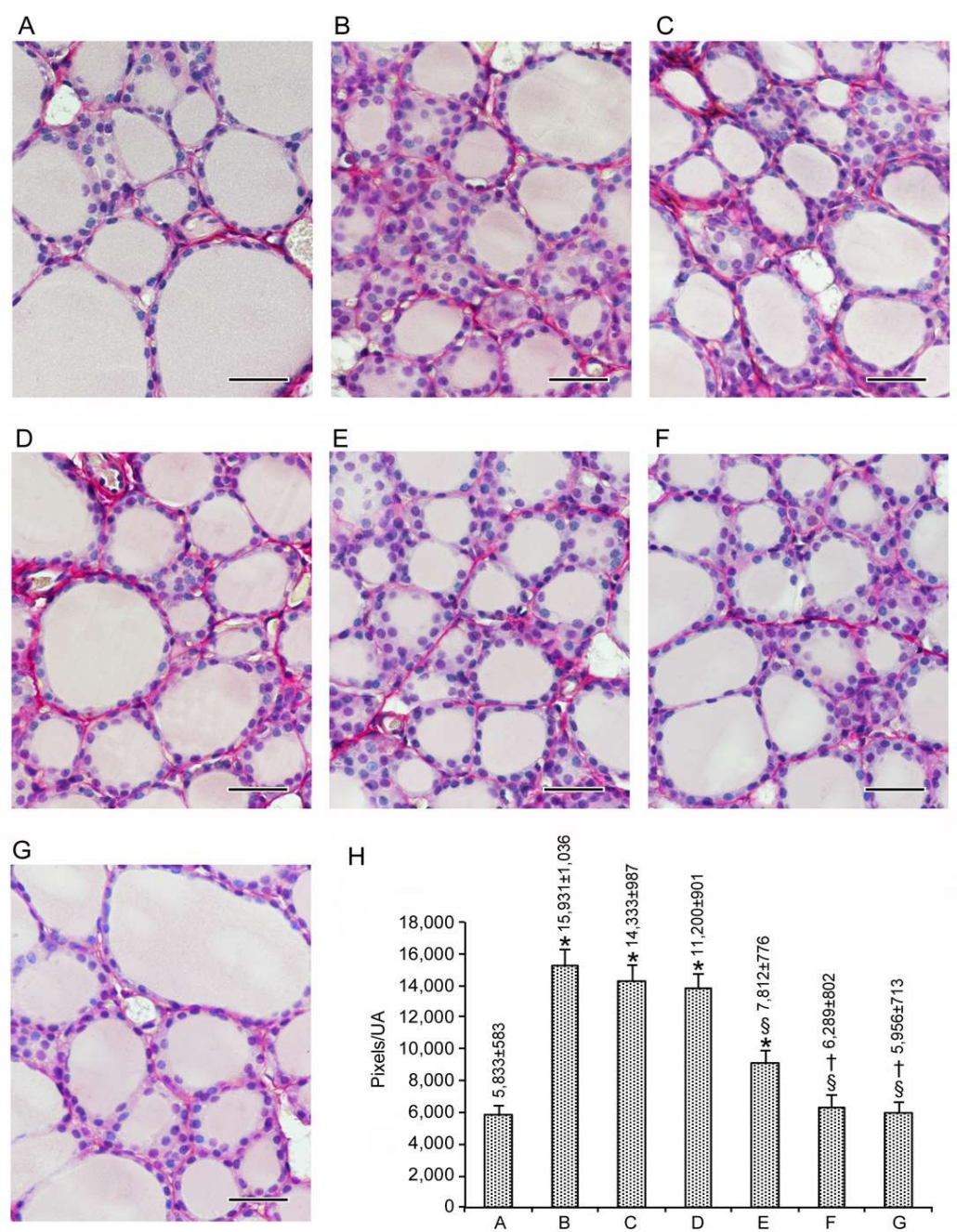

Figure 2. Structural organization of the thyroid stroma based on staining with Sirius Red (scale bar: $25 \mu \mathrm{m}$ ). Mice groups are as in Figure 1. (A): Control mice have a normal architecture of interstitial collagen, with well-stained fibrillary elements, as indicated by bar A in $\mathrm{H}$. (B): In $\mathrm{CdCl}_{2}$-treated mice, an increased amount of perifollicular connective tissue is present around the follicles, as indicated by bar B in $\mathrm{H}$. (C,D): In mice challenged with $\mathrm{CdCl}_{2}$ and $0.2 \mathrm{mg} / \mathrm{kg}$ Se or $\mathrm{CdCl}_{2}$ and $0.4 \mathrm{mg} / \mathrm{kg} \mathrm{Se}$, stained areas are similar to mice challenged with $\mathrm{CdCl}_{2}$, as shown by bars $\mathrm{C}$ and $\mathrm{D}$ in $\mathrm{H}$. (E): $\mathrm{CdCl}_{2}$ plus MI-treated mice have stained areas with a statistically significant decrease in the pink/red colored collagen fibers, as evident in $\mathrm{H}$, bar E. (F,G): In mice treated with $\mathrm{CdCl}_{2}$ plus $\mathrm{MI}$ and $0.2 \mathrm{mg} / \mathrm{kg}$ Se or $\mathrm{CdCl}_{2}$ plus $\mathrm{MI}$ and $0.4 \mathrm{mg} / \mathrm{kg}$ Se, a significant reduction in the stained areas can be seen, as also demonstrated by bars $\mathrm{F}$ and $\mathrm{G}$ in $\mathrm{H}$. $(\mathbf{H})$ : Mean \pm standard error values of pixel numbers of Sirius Red (SR)-stained areas/unit areas (UA) in the different groups of challenged mice. ${ }^{*} p<0.05$ versus control; $\S p<0.05$ versus $\mathrm{CdCl}_{2}$ plus vehicle and $\mathrm{CdCl}_{2}$ plus 0.2 or $0.4 \mathrm{mg} / \mathrm{kg} \mathrm{Se} ;+p<0.05$ versus $\mathrm{CdCl}_{2}$ plus MI.

When comparing Figure $2 \mathrm{H}$ with Figure $1 \mathrm{H}, \mathrm{I}$, it is evident that changes in the stroma were parallel to changes in epithelial height and opposite to changes in follicular area. Compared to the amount of stroma in the seven untreated mice (5912 \pm 556 pixels/UA (data not shown)), in the other 42 control mice, the variation was between $-5.0 \%$ (mice treated with only $0.2 \mathrm{mg} / \mathrm{kg}$ Se) AND $+2.1 \%$ (mice treated 
with vehicle) (data not shown). Accordingly, the value of $5833 \pm 583$ (mean \pm SE of the 49 control mice; Figure 2A and bar A in Figure $2 \mathrm{H}$ ) was taken as the reference to evaluate the effects of $\mathrm{CdCl}_{2}$ alone or $\mathrm{CdCl}_{2}$ co-administered with Se, $\mathrm{MI}$, or their association. Exposure to $\mathrm{CdCl}_{2}$ alone increased the amount of perifollicular connective tissue by almost threefold (compare Figure 2A, $\mathrm{B}$, and bars $\mathrm{A}$ and $\mathrm{B}$ in Figure $2 \mathrm{H}$ ). The co-administration of $\mathrm{CdCl}_{2}$ and Se decreased-even though the $\mathrm{CdCl}_{2}$-induced an insignificant increase in-thyroid connective tissue (compare Figure 2C,D with Figure 2B, and bars C and D with bar B in Figure $2 \mathrm{H}$ ). $\mathrm{MI}$ co-administration was more effective compared to either dose of $\mathrm{Se}$, since the increase in the amount of stroma was of a smaller magnitude (compare Figure 2E with Figure 2C,D, and bar E with bars C-D in Figure $2 \mathrm{H}$ ) or approximately 1.5-fold higher when compared to controls (compare Figure 2E with Figure 2A, and bar E with bar A in Figure 2H). The association of MI with either dose of Se in mice that were simultaneously treated with $\mathrm{CdCl}_{2}$ was even more effective, resulting in an amount of stroma superimposable to that of the control mice (compare Figure 2F, $\mathrm{G}$ with Figure 2A, and bars F-G with bar A in Figure 2H).

In summary, both the follicular epithelium and the connective tissue respond in a similar fashion to the administration of $\mathrm{Se}, \mathrm{MI}$ or their combination in $\mathrm{CdCl}_{2}$ co-treated mice. This response consists of a benefit that is modest in the case of Se, moderate in the case of MI, and high (full protection) in the case of MI combined with either dose of Se.

\subsection{Immunohistochemical Expression of MCP-1/CCL2}

To maintain the modality of illustrating results, images are presented in Figure 3A-G, with quantification also summarized in Figure 3H for MCP-1/CCL2, and in Figure 4A-G, with quantification also summarized in Figure 4H for CXCL10.

In the baseline condition represented by untreated mice, there were no cells at all that expressed MCP-1/CCL2 (data not shown), a pattern that was also true for the vehicle-treated mice and the other groups of control mice, except three groups. These three groups, in which only one cell was stained, were those treated with either concentrations of Se alone and the group treated with $0.4 \mathrm{mg} / \mathrm{kg} \mathrm{Se}$ plus MI (data not shown). Overall, in the 49 mice from the seven control groups, the number of cells immunostained by the MCP-1/CCL2 averaged $0.35 \pm 0.34 / \mathrm{UA}$ (Figure 3A, and bar A in Figure 3H). In contrast, $\mathrm{CdCl}_{2}$ plus the vehicle induced a marked expression of MCP-1/CCL2, with a 60-fold increase in the number of thyrocytes immunostained (compare Figure 3B with Figure 3A, and bar $\mathrm{B}$ with bar $\mathrm{A}$ in Figure $3 \mathrm{H}$ ). In the mice from the remaining groups, the over-expression induced by $\mathrm{CdCl}_{2}$ was counteracted significantly by all of the tested compounds (Figure 3C-G, and bars C-G in Figure $3 \mathrm{H}$ ). This antagonism was small with either the dose of Se alone (Figure 3C,D, and bars C-D in Figure $3 \mathrm{H}$ ), moderate with MI alone (Figure 3E, and bar E in Figure 3H), and great with the dose of Se and MI (Figure 3F-G, and bars F-G in Figure 3H). Indeed, $0.4 \mathrm{mg} / \mathrm{kg}$ Se plus MI decreased the number of cells to $0.44 \pm 0.39$, which is statistically similar to the above $0.35 \pm 0.34$ for the 49 control mice. 
A

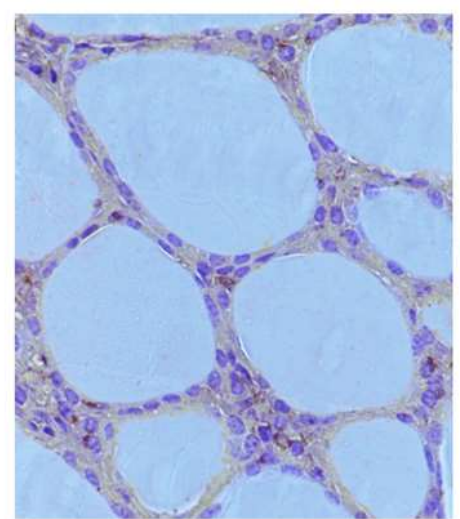

D

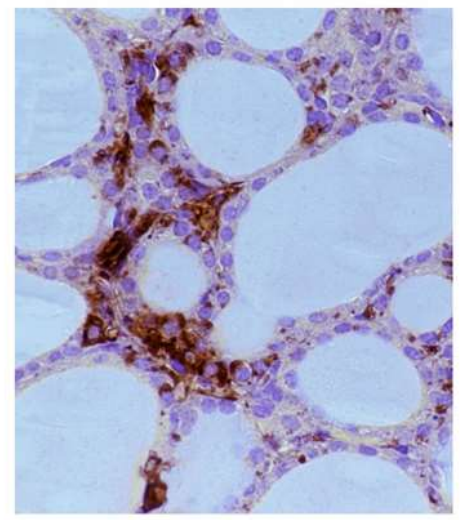

G

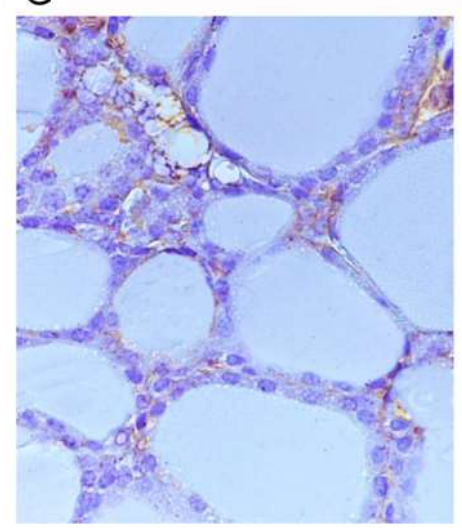

B

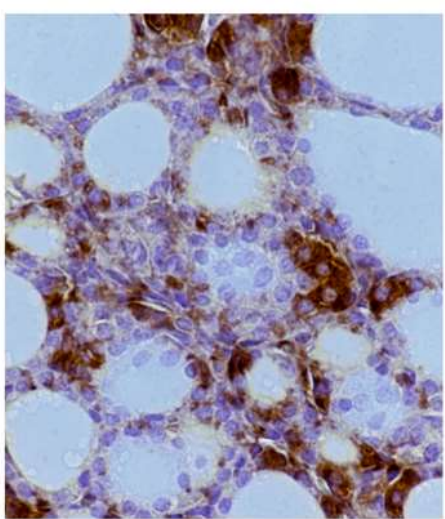

E

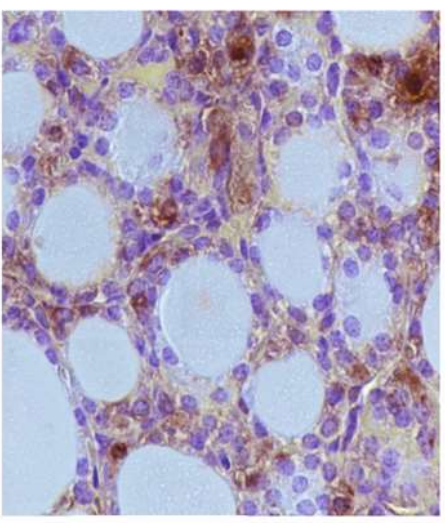

C

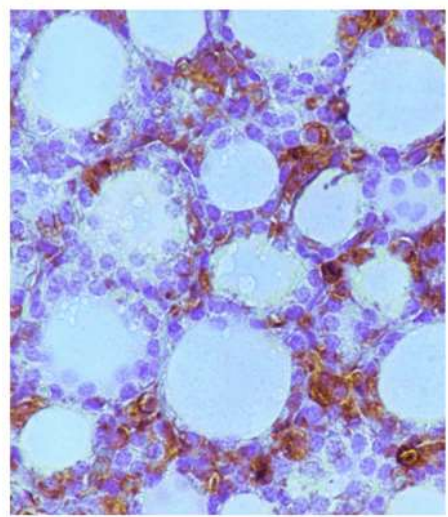

F

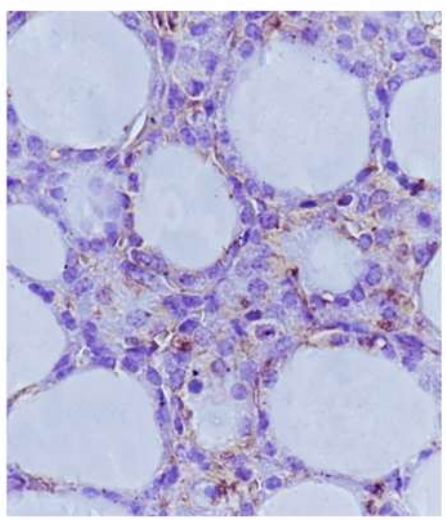

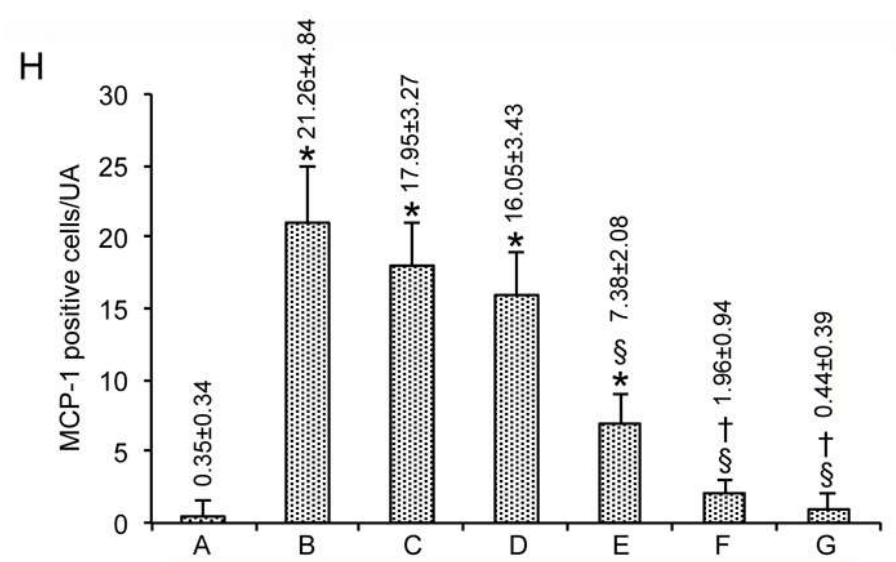

Figure 3. Immunohistochemical expression of monocyte chemoattractant protein-1 (MCP-1) in the thyroid (scale bar: $25 \mu \mathrm{m}$ ). Mice groups are as in Figure 1. (A): In controls, no MCP-1-positive cells are present, as shown by bar $\mathrm{A}$ in $\mathrm{H}$. (B): $\mathrm{CdCl}_{2}$-treated mice show a marked increase in MCP-1 immunoreactivity, as indicated by bar $\mathrm{B}$ in $\mathrm{H}$; positive cells line the follicle wall with strong stains on their cytoplasm. (C,D): In mice treated with $\mathrm{CdCl}_{2}$ plus $0.2 \mathrm{mg} / \mathrm{kg}$ Se or $\mathrm{CdCl}_{2}$ plus $0.4 \mathrm{mg} / \mathrm{kg} \mathrm{Se}$, the number of MCP-1-positive cells is decreased, but still higher than controls, as evidenced by bars $\mathrm{C}$ and $\mathrm{D}$ in $\mathrm{H}$. (E): $\mathrm{CdCl}_{2}$ plus MI-treated mice, MCP-1-positive cells are fewer, as shown by bar $\mathrm{E}$ in $\mathrm{H}$, and show reduced cytoplasmic staining. (F,G): In the thyroid of mice treated with $\mathrm{CdCl}_{2}$ plus $\mathrm{MI}$ and $0.2 \mathrm{mg} / \mathrm{Kg}$ Se or $\mathrm{CdCl}_{2}$ plus $\mathrm{MI}$ and $0.4 \mathrm{mg} / \mathrm{kg}$ Se, MCP- 1 immunoreactivity is significantly decreased, as indicated by bars F-G in H. (H): The number of MCP-1-positive cells per microscopic field in the different groups of mice (mean \pm standard error). ${ }^{*} p<0.05$ versus control; $\S p<0.05$ versus $\mathrm{CdCl}_{2}$ plus vehicle and $\mathrm{CdCl}_{2}$ plus 0.2 or $0.4 \mathrm{mg} / \mathrm{kg}$ Se; $\uparrow p<0.05$ versus $\mathrm{CdCl}_{2}$ plus MI. 
A

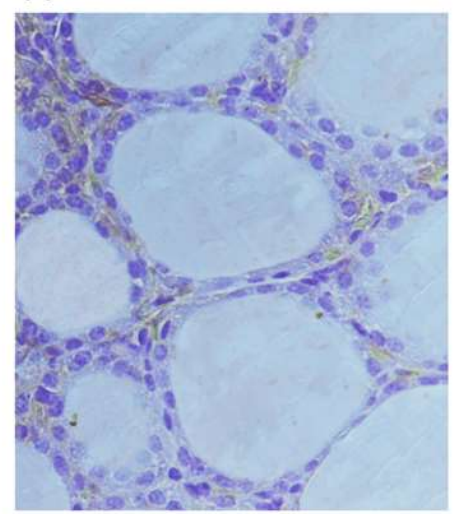

D

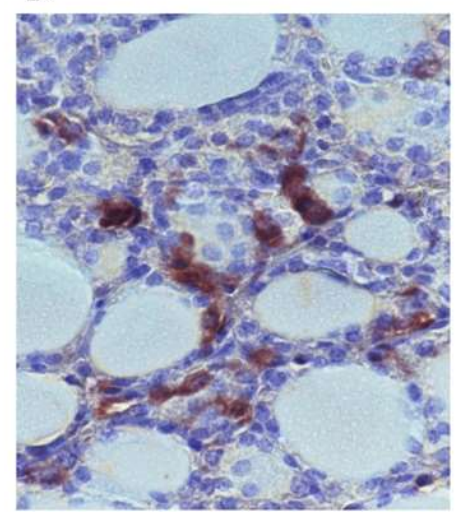

G

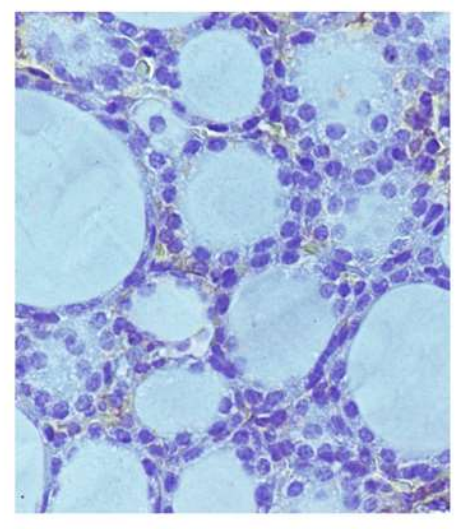

B

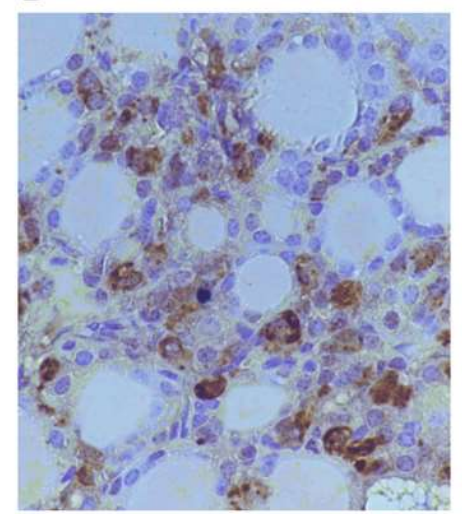

E

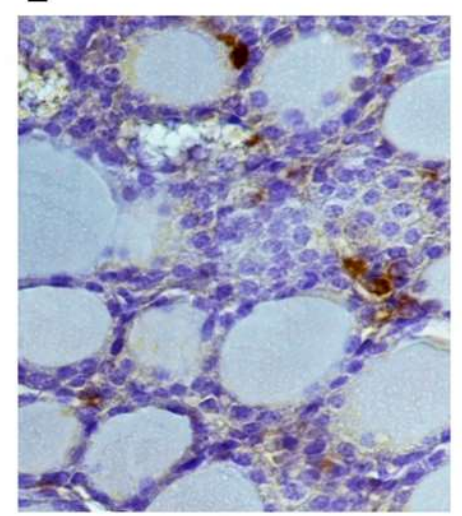

C

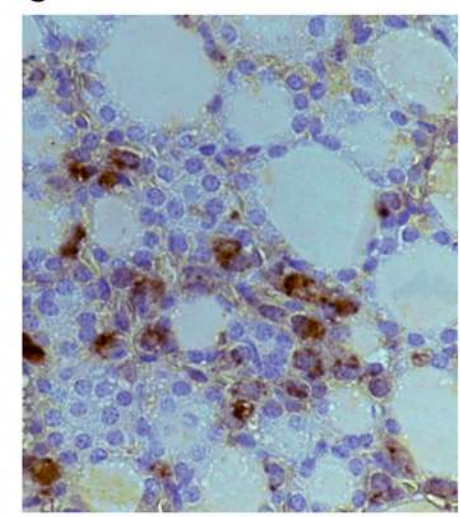

F

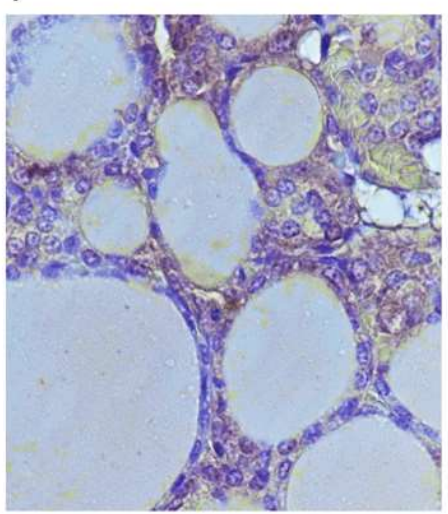

$\mathrm{H}$

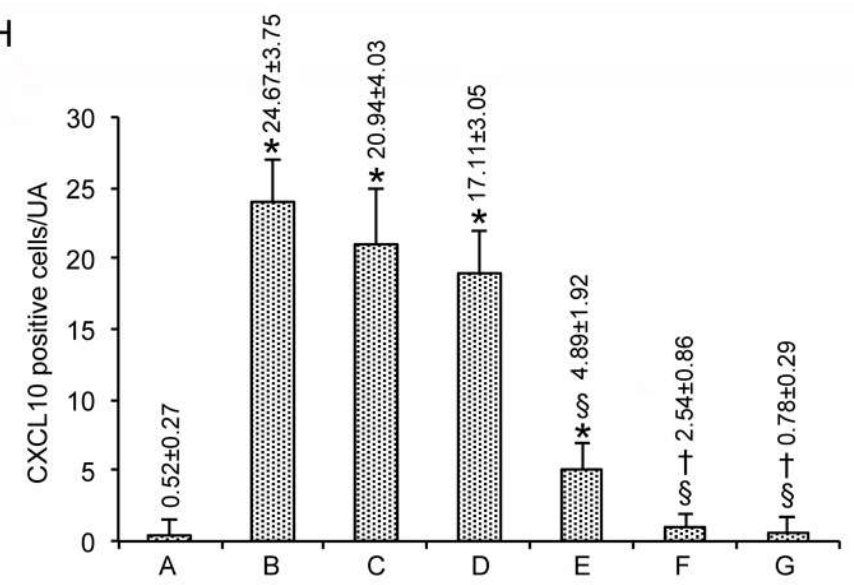

Figure 4. Immunohistochemical expression of C-X-C motif chemokine 10 (CXCL10) in the thyroid (scale bar: $25 \mu \mathrm{m}$ ). Mice groups are as in Figure 1. (A): In controls, no CXCL10-positive cells are evident, as shown by bar A in $\mathrm{H}$. (B): In $\mathrm{CdCl}_{2}$-treated mice, a large number of CXCL10-positive cells is present among the follicle walls, as indicated by bar B in $\mathrm{H}$. (C,D): In mice treated with $\mathrm{CdCl}_{2}$ plus $0.2 \mathrm{mg} / \mathrm{kg}$ Se or $\mathrm{CdCl}_{2}$ plus $0.4 \mathrm{mg} / \mathrm{kg} \mathrm{Se}$, the number of CXCL10-positive cells is decreased, but still high, as evidenced by bars $\mathrm{C}$ and $\mathrm{D}$ in $\mathrm{H}$. (E): In $\mathrm{CdCl}_{2}$ plus MI-treated mice, only a few CXCL10-positive cells are present, as shown by bar E in $\mathrm{H}$. $(\mathrm{F}, \mathrm{G})$ : In the thyroid of $\mathrm{CdCl}_{2}$ plus MI and $0.2 \mathrm{mg} / \mathrm{kg}$ Se or $\mathrm{CdCl}_{2}$ plus MI and $0.4 \mathrm{mg} / \mathrm{kg}$ Se, no CXCL10 immunoreactivity is detectable, as indicated by bars F-G in H. $(\mathbf{H})$ : The number of CXCL10-positive cells per microscopic field in the different groups of mice (mean \pm standard error). ${ }^{*} p<0.05$ versus control; $\S p<0.05$ versus $\mathrm{CdCl}_{2}$ plus vehicle and $\mathrm{CdCl}_{2}$ plus Se 0.2 or $0.4 \mathrm{mg} / \mathrm{kg}$ Se; $\uparrow p<0.05$ versus $\mathrm{CdCl}_{2}$ plus MI. 


\subsection{Immunohistochemical Expression of CXCL10}

When CXCL10 immunoreactivity was considered, the results mimicked those described above for MCP-1/CCL2. Thus, in the 49 mice from the seven control groups, the number of cells immunostained by the CXCL10 averaged $0.52 \pm 0.27 / \mathrm{UA}$ (Figure $4 \mathrm{~A}$, and bar A in Figure $4 \mathrm{H}$ ). The overexpression of CXLC10 induced by $\mathrm{CdCl}_{2}$ plus the vehicle was fully counteracted by the combination of MI with either dose of Se (Figure 4F,G, and bars F-G in Figure 4H).

\section{Discussion}

In the present work, we have confirmed that $\mathrm{Cd}$ exposure has negative consequences for the murine thyroid. These consist of histologically demonstrable alterations in the follicular epithelium and stroma, and in the induced expression of two chemoattractant chemokines, an expression that is absent prior to Cd exposure.

In fact, after chronic exposure to $\mathrm{Cd}$, desquamated cells into the follicles, mononuclear cell infiltration in the stroma and follicles lined by higher cells with light cytoplasm were observed [25]. Therefore, these Cd-elicited thyroid changes have consequences in terms of both thyroid dysfunction and autoimmunity [31,32,54].

Se is considered to exert an overall protection against toxicity induced by heavy metals such as $\mathrm{Cd}$, $\mathrm{Pb}$, As and $\mathrm{Hg}$ [55], mainly through the sequestration of these elements into biologically inert complexes and/or through the action of Se-dependent antioxidant enzymes [55]. This protection from Cd toxicity occurs regardless of the Se form (as selenite, selenomethionine, nanoSe, or Se from lentils) [56]. Furthermore, it was recently demonstrated that Se alleviated oxidative stress in chicken ovari and rat kidneys, and counteracted the endoplasmic reticulum stress able to induce apoptosis [57,58]. However, in this paper, we found that the trace element Se was less potent than the carbocyclic sugar MI in protecting mice from $\mathrm{CdCl}_{2}$ thyroid toxicity, though the co-administration of Se amplified the protection conferred by MI alone. The complementary activity of the two antioxidants can be related to their distinctive mechanism of action. While Se is a vital constituent of the enzyme glutathione peroxidase that catalyzes the reaction between GSH and hydrogen peroxide, thus protecting against oxidative stress, MI is a hydroxyl radical scavenger, preventing lipid peroxidation. The combined action of the two compounds may enhance the antioxidant effect [39]. Interestingly the efficacy of this combination was greater that that of resveratrol (used for its potent antioxidant properties), at least when using the follicular area and the epithelial height as read-outs for a comparison evaluation.

One limitation of our work is the lack of hormone measurements. However, considering (i) the aforementioned Chinese study on the direct relationship between blood Cd levels with thyroid hypofunction and serum thyroid autoantibody levels [31], (ii) the association of insulin resistance with either decreased thyroid hormone levels or increased serum TSH [59-61], with counteracting effects by insulin-sensitizing agents [62-64], and (iii) the insulin-mimetic action of MI [54,65,66], we expected that Cd-exposed mouse thyroids would display decreased thyroid hormone levels and increased TSH compared to Cd-unexposed mice. We also expected that at least the combination of MI+Se would have fully counteracted these hormone changes induced by $\mathrm{Cd}$.

On the other hand, the strengths of this study are the findings that are consistent with the previous literature concerning the benefits for the thyroid [38] and other endocrine organs, such as the testes [39], including consistency in the hierarchy of benefits ( $\mathrm{MI}+\mathrm{Se}>\mathrm{MI}>>\mathrm{Se}$ ). In particular, $\mathrm{CdCl}_{2}$ determined significant increase in MCP-1 and CXCL10-positive cell numbers. Our data clearly agree with many in vitro and in vivo experiments by different groups, showing that the production of these chemokines by thyrocytes may play a central role in the recruitment of monocytes and T-lymphocytes at immune inflammatory sites in the thyroid gland from the blood in humans, thus providing a possible mechanism by which thyrocytes themselves may participate in the processes of thyroid autoimmune and inflammatory disease $[45,46]$. After treatment with Se, MCP-1 and CXCL10-positive cell numbers were reduced. These data about the effects of Se on the thyroid gland, from our point of view, are not particularly surprising. In fact, the recent literature indicates that, regarding thyroid pathology, 
selenium intake has been associated with autoimmune disorders [67]. Our experimental data indicate the relative inefficacy of Se when administered alone, probably due to extensive detrimental effects of $\mathrm{Cd}$ on thyroid structure and function, not adequately counterbalanced by micronutrient administration alone. MI treatment significantly lowered MCP-1 and CXCL10-positive cell numbers, particularly in association with Se, thus confirming that this nutraceutical compound could impact different molecular pathways related to oxidative stress and inflammation, involving chemokines such as MCP-1 and CXCL10 [46].

In view of the "prophylactic" benefit reported in the present paper, it will now be interesting to investigate whether Se, MI and their combination (Se+MI) have "therapeutic" benefits. The demonstration of the latter's benefits requires that animals would be first exposed to $\mathrm{CdCl}_{2}$ for a time sufficient to induce thyroid toxicity (14 days, based on the present work), and then administered Se, MI and Se+MI at doses equal to or greater than those used in the present work and for the same or a longer time ( $\geq 14$ days), in order to show the reversal of the alterations induced by prior $\mathrm{Cd}$ exposure. Another translational implication of the data presented in this paper is that, because several pollutants, such as organochlorine compounds, polychlorinated biphenyls, polybrominated diphenylethers, bisphenol A, triclosan, perchlorates, thiocyanates, nitrates and heavy metals different from $\mathrm{Cd}$ [3-8] disturb thyroid homeostasis and confer increased environmental susceptibility to thyroid autoimmunity, it would be worthwhile to test whether the said molecules (particularly MI+Se) may have prophylactic and/or therapeutic effects against the thyroid alterations caused by exposure to a number of thyroid-disrupting chemicals.

Supplementary Materials: The following are available online at http://www.mdpi.com/2072-6643/12/5/1222/s1, Figure S1: Histological organization of the thyroid (hematoxylin-eosin stain; scale bar: $25 \mu \mathrm{m})$. Mice groups (7 mice/group) are: (A) controls, (B) cadmium chloride $\left(\mathrm{CdCl}_{2}\right)$ plus vehicle, $(\mathrm{C}) \mathrm{CdCl}_{2}$ plus seleno-L-methionine (Se) $0.2 \mathrm{mg} / \mathrm{kg}, \mathrm{CdCl}_{2}$ plus Se $0.4 \mathrm{mg} / \mathrm{kg}$, (E) $\mathrm{CdCl}_{2}$ plus myo-inositol (MI), (F) $\mathrm{CdCl}_{2}$ plus MI plus Se $0.2 \mathrm{mg} / \mathrm{kg}$, $\mathrm{CdCl}_{2}$ plus MI plus Se $0.4 \mathrm{mg} / \mathrm{kg}$. A: Control mice have normal thyroid structure, as demonstrated also by bar A in I and L. B: $\mathrm{CdCl}_{2}$-treated mice show small follicles and less stainable follicular epithelium (thyrocytes), the height of which is increased, as shown by bar B in I and L. C-D: In mice treated with $\mathrm{CdCl}_{2}$ plus $0.2 \mathrm{mg} / \mathrm{Kg} \mathrm{Se}$ or CdCl 2 plus $0.4 \mathrm{mg} / \mathrm{kg} \mathrm{Se}$, small follicles are present with thyrocytes of smaller height, as indicated by bars C and D in I and L. E: In mice treated with $\mathrm{CdCl}_{2}$ plus $\mathrm{MI}$, the follicles and thyrocytes show a tendency to acquire the normal size and height, even though both indices are significantly different from controls; see also bar E in I and L. F-G: In mice treated with $\mathrm{CdCl}_{2}+\mathrm{MI}+0.2 \mathrm{mg} / \mathrm{Kg}$ Se or $\mathrm{CdCl}_{2}+\mathrm{MI}+0.4 \mathrm{mg} / \mathrm{kg}$ Se, follicles and the epithelial cells were close to normal, as demonstrated by bars F and $\mathrm{G}$ in in I and L. H: In mice treated with $\mathrm{CdCl}_{2}$ plus resveratrol, the follicles show an increased size and thyrocytes a reduced height, being both indices significantly different from controls, as shown also by bar H in I and L histograms. I - Mean \pm standard error values of follicular area in the different groups of mice. L - Mean \pm standard error values of epithelial cells height in the different groups of mice. ${ }^{*} p<0.05$ versus control; $\S p<0.05$ versus $\mathrm{CdCl}_{2}$ plus vehicle and $\mathrm{CdCl} 2$ plus 0.2 or $0.4 \mathrm{mg} / \mathrm{kg} \mathrm{Se} ;+p<0.05$ versus $\mathrm{CdCl}_{2}$ plus $\mathrm{MI}$ alone; $\neq p<0.05$ versus $\mathrm{CdCl}_{2}+\mathrm{MI}+0.2 \mathrm{mg} / \mathrm{Kg}$ Se and $\mathrm{CdCl}_{2}+\mathrm{MI}+0.4 \mathrm{mg} / \mathrm{kg} \mathrm{Se}$.

Author Contributions: Conceptualization, S.B., H.R.M., A.M., A.A., F.S., L.M.; methodology and software, A.M., J.F.; formal analysis, D.P., N.I., G.P., D.A., S.B., L.M.; data curation, D.P., A.M., L.M.; writing the first draft of the manuscript, D.P., L.M.; writing sections of the manuscript, S.B., S.M.F., P.F.; reviewing the manuscript, H.R.M., S.B., A.M. All authors have read and agreed to the published version of the manuscript.

Funding: This research did not receive any specific grant from funding agencies in the public, commercial, or not-for-profit sectors.

Acknowledgments: The authors thank LO.LI. Pharma S.r.l. (Rome, Italy) for the kind gift of MI.

Conflicts of Interest: S.B. has been an invited speaker for LO.LI. Pharma, which provided us with pure MI, but had no role in the design of the study; in the collection, analyses, or interpretation of data; in the writing of the manuscript, or in the decision to publish the results. All the other authors declare no conflict of interest.

\section{References}

1. Wiersinga, W.M. Hashimoto's Thyroiditis. In Thyroid Diseases. Pathogenesis, Diagnosis, and Treatment; Vitti, P., Hegedus, L., Eds.; Springer: New York, NY, USA, 2018; pp. 205-247. 
2. Davies, L.; Morris, L.G.; Haymart, M.; Chen, A.Y.; Goldenberg, D.; Morris, J.; Ogilvie, J.B.; Terris, D.J.; Netterville, J.; Wong, R.J.; et al. AACE Endocrine Surgery Scientific Committee. American Association of Clinical Endocrinologists and American College of Endocrinology disease state clinical review: The increasing incidence of thyroid cancer. Endocr. Pract. 2015, 21, 686-696. [CrossRef] [PubMed]

3. Köhrle, J. Environment and endocrinology: The case of thyroidology. Ann. Endocrinol. 2008, 69, 116-122. [CrossRef] [PubMed]

4. Bajaj, J.K.; Salwan, P.; Salwan, S. Various possible toxicants involved in thyroid dysfunction: A review. J. Clin. Diagn. Res. 2016, 10, FE01. [CrossRef] [PubMed]

5. Zoeller, T.R. Environmental chemicals targeting thyroid. Hormones 2010, 9, 28-40. [CrossRef]

6. Maqbool, F.; Mostafalou, S.; Bahadar, H.; Abdollahi, M. Review of endocrine disorders associated with environmental toxicants and possible involved mechanisms. Life Sci. 2016, 145, 265-273. [CrossRef]

7. Buha, A.; Matovic, V.; Antonijevic, B.; Bulat, Z.; Curcic, M.; Renieri, E.A.; Tsatsakis, A.M.; Schweitzer, A.; Wallace, D. Overview of Cadmium Thyroid Disrupting Effects and Mechanisms. Int. J. Mol. Sci. 2018, 19, 1501. [CrossRef]

8. Benvenga, S.; Antonelli, A.; Vita, R. Thyroid nodules and thyroid autoimmunity in the context of environmental pollution. Rev. Endocr. Metab. Disord. 2015, 16, 319-340. [CrossRef]

9. Thévenod, F.; Lee, W.K. Toxicology of cadmium and its damage in mammalian organs. Met. Ions Life Sci. 2013, 11, 415-490. [CrossRef]

10. Margoshes, M.; Vallee, B.L. A cadmium protein from equine kidney cortex. J. Am. Chem. Soc. 1957, 79, 4813-4814. [CrossRef]

11. Klaassen, C.D.; Liu, J.; Diwan, B. Metallothionein protection of cadmium toxicity. Toxicol. Appl. Pharmacol. 2009, 238, 215-220. [CrossRef]

12. Matović, V.; Buha, A.; Bulat, Z.; Đukić-Ćosić, D. Cadmium Toxicity Revisited: Focus on Oxidative Stress Induction and Interactions with Zinc and Magnesium. Arch. Ind. Hyg. Toxicol. 2011, 62, 65-76. [CrossRef]

13. Matović, V.; Buha, A.; Dukić-Ćosić, D.; Bulat, Z. Insight into the oxidative stress induced by lead and/or cadmium in blood, liver and kidneys. Food Chem. Toxicol. 2015, 78, 130-140. [CrossRef] [PubMed]

14. Rinaldi, M.; Micali, A.; Marini, H.; Adamo, E.B.; Puzzolo, D.; Pisani, A.; Trichilo, V.; Altavilla, D.; Squadrito, F.; Minutoli, L. Cadmium, organ toxicity and therapeutic approaches: A review on brain, kidney and testis damage. Curr. Med. Chem. 2017, 24, 3879-3893. [CrossRef] [PubMed]

15. Mezynska, M.; Brzóska, M.M. Environmental exposure to cadmium-A risk for health of the general population in industrialized countries and preventive strategies. Environ. Sci. Pollut. Res. 2018, 25,3211-3232. [CrossRef] [PubMed]

16. Uetani, M.; Kobayashi, E.; Suwazono, Y.; Honda, R.; Nishijo, M.; Nakagawa, H.; Kido, T.; Nogawa, K. Tissue cadmium $(\mathrm{Cd})$ concentrations of people living in a Cd polluted area, Japan. BioMetals 2006, 19, 521-525. [CrossRef]

17. IARC. Personal Habits and Indoor Combustions. In IARC Monographs on the Evaluation of Carcinogenic Risks to Humans; International Agency for Research on Cancer: Lyon, France, 2012; Volume 100.

18. Larsson, S.C.; Orsini, N.; Wolk, A. Urinary cadmium concentration and risk of breast cancer: A systematic review and dose-response meta-analysis. Am. J. Epidemiol. 2015, 182, 375-380. [CrossRef]

19. Buha, A.; Wallace, D.; Matovic, V.; Schweitzer, A.; Oluic, B.; Micic, D.; Djordjevic, V. Cadmium Exposure as a Putative Risk Factor for the Development of Pancreatic Cancer: Three Different Lines of Evidence. Biomed. Res. Int. 2017, 2017, 1-8. [CrossRef]

20. Feki-Tounsi, M.; Hamza-Chaffai, A. Cadmium as a possible cause of bladder cancer: A review of accumulated evidence. Environ. Sci. Pollut. Res. 2014, 21, 10561-10573. [CrossRef]

21. Stojsavljević, A.; Rovčanin, B.; Krstić, Đ.; Jagodić, J.; Borković-Mitić, S.; Paunović, I.; Živaljević, V.; Mitić, B.; Gavrović-Jankulović, M.; Manojlović, D. Cadmium as main endocrine disruptor in papillary thyroid carcinoma and the significance of $\mathrm{Cd} / \mathrm{Se}$ ratio for thyroid tissue pathophysiology. J. Trace Elem. Med. Biol. 2019, 55, 190-195. [CrossRef]

22. Hammouda, F.; Messaoudi, I.; El Hani, J.; Baati, T.; Saïd, K.; Kerkeni, A. Reversal of cadmium-induced thyroid dysfunction by selenium, zinc, or their combination in rat. Biol. Trace Elem. Res. 2008, 126, 194-203. [CrossRef] 
23. Buha, A.; Antonijević, B.; Bulat, Z.; Jaćević, V.; Milovanović, V.; Matović, V. The impact of prolonged cadmium exposure and co-exposure with polychlorinated biphenyls on thyroid function in rats. Toxicol. Lett. 2013, 221, 83-90. [CrossRef] [PubMed]

24. Jancic, S.A.; Stosic, B.Z. Cadmium effects on the thyroid gland. Vitam. Horm. 2014, 94, 391-425. [CrossRef] [PubMed]

25. Piłat-Marcinkiewicz, B.; Brzóska, M.M.; Sawicki, B.; Moniuszko-Jakoniuk, J. Structure and function of thyroid follicular cells in female rats chronically exposed to cadmium. Bull. Vet. Inst. Pulawy 2003, 47, 157-163.

26. Aaseth, J.; Frey, H.; Glattre, E.; Norheim, G.; Ringstad, J.; Thomassen, Y. Selenium concentrations in the human thyroid gland. Biol. Trace Elem. Res. 1990, 24, 147-152. [CrossRef]

27. Köhrle, J.; Jakob, F.; Contempré, B.; Dumont, J.E. Selenium, the thyroid, and the endocrine system. Endocr. Rev. 2005, 26, 944-984. [CrossRef]

28. Köhrle, J. Selenium and the thyroid. Curr. Opin. Endocrinol. Diabetes Obes. 2015, 22, 392-401. [CrossRef]

29. Duntas, L.H.; Benvenga, S. Selenium: An element for life. Endocrine 2015, 48, 756-775. [CrossRef]

30. Ralston, N.V.; Raymond, L.J. Dietary selenium's protective effects against methylmercury toxicity. Toxicology 2010, 278, 112-123. [CrossRef]

31. Nie, X.; Chen, Y.; Chen, Y.; Chen, C.; Han, B.; Li, Q.; Zhu, C.; Xia, F.; Zhai, H.; Wang, N.; et al. Lead and cadmium exposure, higher thyroid antibodies and thyroid dysfunction in Chinese women. Environ. Pollut. 2017, 230, 320-328. [CrossRef]

32. Chung, S.M.; Moon, J.S.; Yoon, J.S.; Won, K.C.; Lee, H.W. Sex-specific effects of blood cadmium on thyroid hormones and thyroid function status: Korean nationwide cross-sectional study. J. Trace Elem. Med. Biol. 2019, 53, 55-61. [CrossRef]

33. Ogawa, Y.; Itoh, M.; Hirai, S.; Suna, S.; Naito, M.; Qu, N.; Terayama, H.; Ikeda, A.; Miyaso, H.; Matsuno, Y.; et al. Cadmium exposure increases susceptibility to testicular autoimmunity in mice. J. Appl. Toxicol. 2013, 33, 652-660. [CrossRef] [PubMed]

34. Monastero, R.N.; Vacchi-Suzzi, C.; Marsit, C.; Demple, B.; Meliker, J.R. Expression of Genes Involved in Stress, Toxicity, Inflammation, and Autoimmunity in Relation to Cadmium, Mercury, and Lead in Human Blood: A Pilot Study. Toxics 2018, 6, 35. [CrossRef] [PubMed]

35. Rani, A.; Kumar, A.; Lal, A.; Pant, M. Cellular mechanisms of cadmium-induced toxicity: A review. Int. J. Environ. Health Res. 2014, 24, 378-399. [CrossRef] [PubMed]

36. Bekheet, S.H. Comparative effects of repeated administration of cadmium chloride during pregnancy and lactation and selenium protection against cadmium toxicity on some organs in immature rats' offsprings. Biol. Trace Elem. Res. 2011, 144, 1008-1023. [CrossRef] [PubMed]

37. Badr, G.M.; Elsawy, H.; Sedky, A.; Eid, R.; Ali, A.; Abdallah, B.M.; Alzahrani, A.M.; Abdel-Moneim, A.M. Protective effects of quercetin supplementation against short-term toxicity of cadmium-induced hematological impairment, hypothyroidism, and testicular disturbances in albino rats. Environ. Sci. Pollut. Res. Int. 2019, 26, 8202-8211. [CrossRef] [PubMed]

38. Benvenga, S.; Feldt-Rasmussen, U.; Bonofiglio, D.; Asamoah, E. Nutraceutical Supplements in the Thyroid Setting: Health Benefits beyond Basic Nutrition. Nutrients 2019, 11, 2214. [CrossRef]

39. Benvenga, S.; Micali, A.; Pallio, G.; Vita, R.; Malta, C.; Puzzolo, D.; Irrera, N.; Squadrito, F.; Altavilla, D.; Minutoli, L. Effects of Myo-inositol Alone and in Combination with Seleno-L-methionine on Cadmium-Induced Testicular Damage in Mice. Curr. Mol. Pharmacol. 2019, 12, 311-323. [CrossRef]

40. Pallio, G.; Micali, A.; Benvenga, S.; Antonelli, A.; Marini, H.R.; Puzzolo, D.; Macaione, V.; Trichilo, V.; Santoro, G.; Irrera, N.; et al. Myo-inositol in the protection from cadmium-induced toxicity in mice kidney: An emerging nutraceutical challenge. Food Chem. Toxicol. 2019, 132, 110675. [CrossRef]

41. Condorelli, R.A.; La Vignera, S.; Di Bari, F.; Unfer, V.; Calogero, A.E. Effects of myoinositol on sperm mitochondrial function in-vitro. Eur. Rev. Med. Pharmacol. Sci. 2011, 15, 129-134.

42. Condorelli, R.A.; La Vignera, S.; Bellanca, S.; Vicari, E.; Calogero, A.E. Myoinositol: Does it improve sperm mitochondrial function and sperm motility? Urology 2012, 79, 1290-1295. [CrossRef]

43. Caprio, F.; D’Eufemia, M.D.; Trotta, C.; Campitiello, M.R.; Ianniello, R.; Mele, D.; Colacurci, N. Myo-inositol therapy for poor-responders during IVF: A prospective controlled observational trial. J. Ovarian Res. 2015, 8 , 37. [CrossRef] 
44. Jiang, W.D.; Wu, P.; Kuang, S.Y.; Liu, Y.; Jiang, J.; Hu, K.; Li, S.H.; Tang, L.; Feng, L.; Zhou, X.Q. Myo-inositol prevents copper-induced oxidative damage and changes in antioxidant capacity in various organs and the enterocytes of juvenile Jian carp (Cyprinus carpio var. Jian). Aquat. Toxicol. 2011, 105, 543-551. [CrossRef] [PubMed]

45. Kasai, K.; Banba, N.; Motohashi, S.; Hattori, Y.; Manaka, K.; Shimoda, S.I. Expression of monocyte chemoattractant protein-1 mRNA and protein in cultured human thyrocytes. FEBS Lett. 1996, 394, 137-140. [CrossRef]

46. Fallahi, P.; Ferrari, S.M.; Elia, G.; Ragusa, F.; Paparo, S.R.; Caruso, C.; Guglielmi, G.; Antonelli, A. Myo-inositol in autoimmune thyroiditis, and hypothyroidism. Rev. Endocr. Metab. Disord. 2018, 19, 349-354. [CrossRef]

47. Ferrari, S.M.; Fallahi, P.; Di Bari, F.; Vita, R.; Benvenga, S.; Antonelli, A. Myo-inositol and selenium reduce the risk of developing overt hypothyroidism in patients with autoimmune thyroiditis. Eur. Rev. Med. Pharmacol. Sci. 2017, 21, 36-42. [PubMed]

48. Benvenga, S.; Vicchio, T.; Di Bari, F.; Vita, R.; Fallahi, P.; Ferrari, S.M.; Catania, S.; Costa, C.; Antonelli, A. Favorable effects of myo-inositol, selenomethionine or their combination on the hydrogen peroxide-induced oxidative stress of peripheral mononuclear cells from patients with Hashimoto's thyroiditis: Preliminary in vitro studies. Eur. Rev. Med. Pharmacol. Sci. 2017, 21, 89-101. [PubMed]

49. Nordio, M.; Basciani, S. Treatment with Myo-Inositol and Selenium Ensures Euthyroidism in Patients with Autoimmune Thyroiditis. Int. J. Endocrinol. 2017, 2017, 2549491. [CrossRef]

50. Gupta, P.; Kar, A. Role of ascorbic acid in cadmium-induced thyroid dysfunction and lipid peroxidation. J. Appl. Toxicol. 1998, 18, 317-320. [CrossRef]

51. Eleawa, S.M.; Alkhateeb, M.A.; Alhashem, F.H.; Bin-Jaliah, I.; Sakr, H.F.; Elrefaey, H.M.; Elkarib, A.O.; Alessa, R.M.; Haidara, M.A.; Shatoor, A.S.; et al. Resveratrol reverses cadmium chloride-induced testicular damage and subfertility by downregulating p53 and Bax and upregulating gonadotropins and Bcl-2 gene expression. J. Reprod. Dev. 2014, 60, 115-127. [CrossRef]

52. Rafati, A.; Hoseini, L.; Babai, A.; Noorafshan, A.; Haghbin, H.; Karbalay-Doust, S. Mitigating Effect of Resveratrol on the Structural Changes of Mice Liver and Kidney Induced by Cadmium; A Stereological Study. Prev. Nutr. Food Sci. 2015, 20, 266-275. [CrossRef]

53. Salehi, B.; Mishra, A.P.; Nigam, M.; Sener, B.; Kilic, M.; Sharifi-Rad, M.; Fokou, P.; Martins, N.; Sharifi-Rad, J. Resveratrol: A Double-Edged Sword in Health Benefits. Biomedicines 2018, 6, 91. [CrossRef] [PubMed]

54. Giammanco, M.; Leto, G. Selenium and autoimmune thyroiditis. EC Nutr. 2019, 14, 449-450.

55. Rahman, M.M.; Hossain, K.F.B.; Banik, S.; Sikder, M.T.; Akter, M.; Bondad, S.E.C.; Rahaman, M.S.; Hosokawa, T.; Saito, T.; Kurasaki, M. Selenium and zinc protections against metal-(loids)-induced toxicity and disease manifestations: A review. Ecotoxicol. Environ. Saf. 2019, 168, 146-163. [CrossRef] [PubMed]

56. Zwolak, I. The Role of Selenium in Arsenic and Cadmium Toxicity: An Updated Review of Scientific Literature. Biol. Trace Elem. Res. 2020, 193, 44-63. [CrossRef] [PubMed]

57. Wan, N.; Xu, Z.; Liu, T.; Min, Y.; Li, S. Ameliorative Effects of Selenium on Cadmium-Induced Injury in the Chicken Ovary: Mechanisms of Oxidative Stress and Endoplasmic Reticulum Stress in Cadmium-Induced Apoptosis. Biol. Trace Elem. Res. 2018, 184, 463-473. [CrossRef]

58. Chen, Z.J.; Chen, J.X.; Wu, L.K.; Li, B.Y.; Tian, Y.F.; Xian, M.; Huang, Z.P.; Yu, R.A. Induction of Endoplasmic Reticulum Stress by Cadmium and Its Regulation on Nrf2 Signaling Pathway in Kidneys of Rats. Biomed. Environ. Sci. 2019, 32, 1-10. [CrossRef]

59. Benvenga, S.; Antonelli, A. Inositol(s) in thyroid function, growth and autoimmunity. Rev. Endocr. Metab. Disord. 2016, 17, 471-484. [CrossRef]

60. Brenta, G.; Caballero, A.S.; Nunes, M.T. Case finding for hypothyroidism should include type 2 diabetes and metabolic syndrome patients: A Latin American Thyroid Society (LATS) position statement. Endocr. Pract. 2019, 25, 101-105. [CrossRef]

61. Chang, Y.C.; Hua, S.C.; Chang, C.H.; Kao, W.Y.; Lee, H.L.; Chuang, L.M.; Huang, Y.T.; Lai, M.S. High TSH Level within Normal Range Is Associated with Obesity, Dyslipidemia, Hypertension, Inflammation, Hypercoagulability, and the Metabolic Syndrome: A Novel Cardiometabolic Marker. J. Clin. Med. 2019, 8, 817. [CrossRef]

62. Lupoli, R.; Di Minno, A.; Tortora, A.; Ambrosino, P.; Lupoli, G.A.; Di Minno, M.N. Effects of treatment with metformin on TSH levels: A meta-analysis of literature studies. J. Clin. Endocrinol. Metab. 2014, 99, E143-E148. [CrossRef] 
63. Dimic, D.; Golubovic, M.V.; Radenkovic, S.; Radojkovic, D.; Pesic, M. The effect of metformin on TSH levels in euthyroid and hypothyroid newly diagnosed diabetes mellitus type 2 patients. Bratisl. Med. J. 2016, 117, 433-435. [CrossRef] [PubMed]

64. Wang, J.; Gao, J.; Fan, Q.; Li, H.; Di, Y. The Effect of Metformin on Thyroid-Associated Serum Hormone Levels and Physiological Indexes: A Meta-Analysis. Curr. Pharm. Des. 2019, 25, 3257-3265. [CrossRef] [PubMed]

65. D'Anna, R.; Di Benedetto, A.; Scilipoti, A.; Santamaria, A.; Interdonato, M.L.; Petrella, E.; Neri, I.; Pintaudi, B.; Corrado, F.; Facchinetti, F. Myo-inositol Supplementation for Prevention of Gestational Diabetes in Obese Pregnant Women: A Randomized Controlled Trial. Obstet. Gynecol. 2015, 126, 310-315. [CrossRef] [PubMed]

66. D'Anna, R.; Santamaria, A.; Alibrandi, A.; Corrado, F.; Di Benedetto, A.; Facchinetti, F. Myo-Inositol for the Prevention of Gestational Diabetes Mellitus. A Brief Review. J. Nutr. Sci. Vitaminol. 2019, 65, S59-S61. [CrossRef]

67. Ventura, M.; Melo, M.; Carrilho, F. Selenium and Thyroid Disease: From Pathophysiology to Treatment. Int. J. Endocrinol. 2017, 2017, 1297658. [CrossRef]

(C) 2020 by the authors. Licensee MDPI, Basel, Switzerland. This article is an open access article distributed under the terms and conditions of the Creative Commons Attribution (CC BY) license (http://creativecommons.org/licenses/by/4.0/). 